\title{
AIR KELAPA TERFERMENTASI SEBAGAI ZAT PENGATUR TUMBUH PADA TANAMAN SAWI (Brasica juncea L.)
}

\author{
FERMENTED COCONUT WATER AS A GROWTH REGULATOR \\ IN MUSTARD PLANTS (Brasica juncea L.)
}

\author{
Elik Murni Ningtias Ningsih ${ }^{1)}$, Yuni Agung Nugroho ${ }^{1)}$ \\ 1) Program Studi Agroteknologi Fakultas Pertanian Universitas Widyagama Malang \\ Email: elikmurni@widyagama.ac.id (penulis korespondensi)
}

\begin{abstract}
ABSTRAK
Zat/hormon pengatur tumbuh memegang peranan untuk memacu pertumbuhan tanaman. Zat pengatur tumbuh kelompok auxin mampu memacu pertumbuhan tanaman dengan mempercepat pembesaran sel tanaman. Pemberian zat pengatur tumbuh auxin dari air kelapa terfermentasi pada pembibitan akan memacu pertumbuhan bibit tanaman yang selanjutnya dapat memacu pertumbuhan tanaman. Penelitian bertujuan untuk mengetahui pertumbuhan tanaman dengan pengaplikasian air kelapa terfermentasi. Penelitian menggunakan Rancangan Acak Lengkap (RAL) dengan 5 perlakuan dan 4 ulangan. Perlakuan terdiri dari $\mathrm{K} 0=$ tanpa pemberian air kelapa, $\mathrm{K} 1=$ pemberian air kelapa terfermentasi dengan air $(1: 1), \mathrm{K} 2$ = pemberian air kelapa terfermentasi dengan air $(1: 2), \mathrm{K} 3$ = pemberian air kelapa terfermentasi dengan air $(1: 3), \mathrm{K} 4=$ pemberian air kelapa terfermentasi dengan air (1:4). Pengamatan pertumbuhan pada parameter panjang tanaman dan jumlah daun, mulai umur 20 hst sampai umur 60 hst. Pengamatan hasil pada umur 60 hst, meliputi berat basah tanaman dan berat kering tanaman sawi. Analisis data menggunakan anova, uji rata-rata perlakuan menggunakan beda nyata jujur (BNJ). Perlakuan aplikasi air kelapa yang difermentasi mengandung zat pengatur tumbuh auxin mempengaruhi pembentukan panjang tanaman dan jumlah daun tanaman sawi pada umur 20 sampai 60 hst. Perlakuan P2 menghasilkan berat basah 119,14 g/tnm dan bering tanaman $8.85 \mathrm{~g} /$ tanaman yang tertinggi saat panen.
\end{abstract}

Kata Kunci : air kelapa, fermentasi, zat pengatur tumbuh, tanaman sawi

\begin{abstract}
Growth regulators substances/hormone play a role to stimulate plant growth. The growth regulators of the auxin group are able to stimulate plant growth by accelerating the enlargement of plant cells. Provision of growth regulator auxin from fermented coconut water in nurseries will stimulate the growth of plant seeds which in turn can stimulate plant growth. The aim of the study was to determine plant growth by applying fermented coconut water. The study used a completely randomized design (CRD) with 5 treatments and 4 replications. The treatments consisted of $K 0=$ without giving coconut water, $K 1$ $=$ giving fermented coconut water with water $(1: 1)$ ratio, $K 2=$ giving fermented coconut water with water $(1: 2)$ ratio, $K 3=$ giving fermented coconut water with water (1:3) ratio, $K 4=$ giving fermented coconut water with water $(1: 4)$ ratio. Observation on the growth of plant length and number of leaves, from the age of 20 day after planting (DAP) to 60 DAP. Observation results at the mustard age of
\end{abstract}


60 DAP, including the wet weight of the plant and the dry weight of the mustard plant. Analysis of the data using ANOVA, test the average treatment using Tukey Test. The application treatment of fermented coconut water containing the growth regulator auxin affects the formation of plant length and number of leaves of mustard plants at the age of 20 to 60 days after planting. The P2 treatment resulted in a fresh weight of $119.14 \mathrm{~g} / \mathrm{plant}$ and a dry weigtht of $8.85 \mathrm{~g} /$ plant which was the highest yield at harvest.

Keywords: coconut water, fermentation, growth regulator, mustard plant

\section{PENDAHULUAN}

Hormon/zat pengatur tumbuh (ZPT) memegang peran dalam meningkatkan pertumbuhan tanaman. Zat pengatur tumbuh tanaman secara alami diproduksi oleh tanaman. Zat pengatur tumbuh berupa senyawa organik kompleks yang berpengaruh pada pertumbuhan dan perkembangan tanaman. Zat pengatur tumbuh diberikan pada tanaman agar meningkatkan pembentukan hormon tanaman (fitohormon) berada di tanaman atau mensibstusi jika hormon dalam tanaman kurang optimal menghasilkan hormon (Dewi, Suryanggono dan Agustiyani. 2016). Hormon pengatur tumbuh terbagi dalam lima golongan yaitu auksin, giberelin, sitokinin, etilen dan asam absisat. Setiap zat pengatur tumbuh mempunyai peranan masing-masing. Zat-zat tersebut sebagai pengatur pertumbuhan dan morfogenesis pada pertumbuhan sel, jaringan dan organ dalam tanaman budidaya. Auksin yang diaplikasikan pada tingkat sel tanaman selanjutnya berpengaruh pada aliran cairan sel/protoplasma dan peningkatan enzim untuk proses metabolisme tanaman. Mekanisme pengaturan kimiawi berhubungan dengan auksin. Auksin berhubungan dengan banyak mekanisme pengaturan kimiawi yang lain dengan mudah dibawa dari arah pucuk ke bawah (basipetal) ke seluruh bagian tanaman (Yunita, Meiriani, Barus, 2017).

Sumber zat pengatur tumbuh alami dihasilkan oleh bagian jaringan tanaman dan hasil tanaman. Salah satu ZPT alami ada pada air kelapa. Agampodi dan Jayawerdana (2007) melaporkan adanya zat pengatur tumbuh di dalam air kelapa yang terdiri dari indole acetic acid/IAA, GA dan kinetin. Yong, et al. (2009), 
melaporkan bahwa dalam air kelapa mengandung auxin berupa IAA. Di dalam $1000 \mathrm{ml}$ air kelapa terdapat auxin sebanyak $0.07 \mathrm{mg}$. Djamhuri (2011) melaporkan bahwa 100 ppm NAA serta 100 ppm IBA pengaruhnya tidak berbeda dengan 100 ppm air kelapa yang diberikan untuk memacu pertumbuhan vegetatif tanaman berupa stek pucuk dan pemberian pada pembibitan. Auksin berupa senyawa IBA mempunyai aktivitas tinggi dalam memacu pembelahan sel (Yunus, et al. 2016).

Pemberian zat pengatur tumbuh mempengaruhi pertumbuhan tanaman. Seswita (2010) dalam penelitiannya melaporkan bahwa pada multiplikasi tunas temulawak dengan perlakuan air kelapa pada berbagai konsentrasi yang diaplikasikan pada media dasar Murashige dan Skog, menunjukkan perlakuan air kelapa pada konsentrasi 10, 15 dan $20 \%(\mathrm{v} / \mathrm{v})$ menunjukkan pengaruhnya terhadap pembentukan tunas, tinggi, jumlah daun dan jumlah akar pada umur 2 bulan setelah tanam.

Pertumbuhan benih tanaman sawi dapat dipacu pertumbuhannya dengan pemberian hormon/zat pengatur tumbuh. Pemberian zat pengatur tumbuh yang berasal dari air kelapa akan memacu tumbuhnya sel yang besar pada saat perkecambahan tanaman (Seswita, 2010). Penambahan ukuran sel disebabkan oleh bertambahnya cairan sel/protoplasma semakin meningkat. Penelitian ini bertujuan untuk mengetahui pengaruh aplikasi air kelapa terfermentasi yang mengandung zat pengatur tumbuh pada pertumbuhan tanaman sawi.

\section{METODE}

Penelitian dilaksanakan di lahan percobaan Universitas Widyagama, Malang. Bahan penelitian terdiri dari benih sawi, air kelapa hibrida, polybag, pupuk organik.

Penelitian menggunakan rancangan lingkungan berupa Rancangan Acak Lengkap (RAL) dengan 5 perlakuan dan 4 ulangan. Perlakuan terdiri dari $\mathrm{K} 0=$ tidak diberi air kelapa, $\mathrm{K} 1$ = pemberian air kelapa terfermentasi dengan air (1 : 1), $\mathrm{K} 2$ = pemberian air kelapa yang difermentasi dengan air (1:2), K3 = pemberian air kelapa yang difermentasi dengan air (1:3), K4 = 
pemberian air kelapa yang difermentasi dengan air $(1: 4)$.

Percobaan dilakukan dengan penyiapan bahan air kelapa hibrida. Setiap liter air kelapa dicampur dengan $10 \mathrm{mg}$ senyawa tryptophan. Acetobacter sp. berperan sebagai pengurai sebanyak $1 \mathrm{ml}$ ke dalam 1 liter susu sapi. Inkubasi susu selama satu hari pada kisaran suhu 35 - 39 ${ }^{\circ} \mathrm{C}$. Air kelapa ditambah $10 \mathrm{ml}$ starter dan difermentasi selama 96 jam pada kisaran suhu $35-39{ }^{\circ} \mathrm{C}$.

Perendaman benih tanaman sawi dalam larutan air kelapa terfermentasi sesuai perlakuan masing-masing selama 10 menit. Benih tanaman sawi ditanam pada kedalaman lebih kurang $0.5 \mathrm{~cm}$. Pemeliharaan tanaman dilakukan dengan melakukan penyiraman sesuai dengan kondisi cuaca. Penyiangan gulma yang tumbuh dan pengendalian fisik dilakukan untuk mengendalikan hama tanaman.

Pengamatan dilakukan pada parameter pertumbuhan tanaman sawi berupa pertumbuhan panjang tanaman dan jumlah daun yang terbentuk (umur 20 hst - 60 hst.). Pengamatan saat panen berupa hasil panen (berat basah tanaman) dan berat kering tanaman sawi/biomassa yang dihasilkan tanaman. Analisis varian (analyzed of variance) pada taraf $\alpha=5 \%$ untuk mengetahui pengaruh perlakuan. Jika berpengaruh nyata dilakukan uji ratarata perlakuan dengan Uji Beda Nyata Jujur (BNJ) pada level $\mathrm{P} \leq$ 0,05 .

\section{HASIL DAN PEMBAHASAN}

Pemberian air kelapa terfermentasi yang terdapat zat pengatur tumbuh auxin pada benih tanaman sawi mempengaruhi pertumbuhan tanaman sawi. Perlakuan pemberian limbah air kelapa terfermentasi yang mengandung zat pengatur tumbuh auxin pada tanaman sawi mempengaruhi panjang tanaman sawi yang berbeda (Tabel 1). 
Tabel 1. Analisa rata-rata panjang tanaman sawi $(\mathrm{cm})$ pada perlakuan pemberian air kelapa terfermentasi

\begin{tabular}{cccccc}
\hline Perlakuan & $20 \mathrm{hst}$ & $30 \mathrm{hst}$ & $40 \mathrm{hst}$ & $50 \mathrm{hst}$ & $60 \mathrm{hst}$ \\
\hline P0 & $17.10 \mathrm{a}$ & $19.05 \mathrm{a}$ & $21.10 \mathrm{a}$ & $25.12 \mathrm{a}$ & $30.07 \mathrm{a}$ \\
P1 & $17.72 \mathrm{ab}$ & $21.22 \mathrm{c}$ & $23.05 \mathrm{~b}$ & $27.62 \mathrm{bc}$ & $32.20 \mathrm{~b}$ \\
P2 & $20.25 \mathrm{c}$ & $23.25 \mathrm{~d}$ & $25.27 \mathrm{~d}$ & $30.17 \mathrm{~d}$ & $35.20 \mathrm{c}$ \\
P3 & $21.20 \mathrm{~b}$ & $23.07 \mathrm{~b}$ & $23.20 \mathrm{c}$ & $28.12 \mathrm{c}$ & $32.18 \mathrm{~b}$ \\
P4 & $18.25 \mathrm{~b}$ & $21.37 \mathrm{c}$ & $23.12 \mathrm{bc}$ & $27.60 \mathrm{~b}$ & $32.22 \mathrm{~b}$ \\
\hline
\end{tabular}

Keterangan : Angka pada satu kolom dengan diikuti huruf sama menunjukkan tidak berbeda nyata (uji BNJ, $\alpha \leq 0.05$ dengan aplikasi program SPSS).

hst : hari setelah tanam

Perlakuan P0 berbeda nyata dengan perlakuan lainnya. Perlakuan P0 tanpa pemberian air kelapa terfermentasi yang mengandung zat pengatur pertumbuhan tanaman menghasikan panjang tanaman sawi paling rendah, sedangkan air kelapa terfermentasi yang mengandung zat pengatur tumbuh auxin meningkatkan pertambahan panjang tanaman sawi. Perendaman benih tanaman sawi pada air kelapa terfermentasi yang mengandung zat pengatur tumbuh auxin dapat mempercepat pertumbuhan sel muda yang tumbuh/meristematis tanaman khususnya pada sel-sel muda/meristem apikal saat pembibitan sampai pertumbuhan tanaman sehingga meningkatkan panjang tanaman sawi. Air kelapa mengandung zat pemacu pertumbuhan yang mampu memacu pertumbuhan tanaman. Pemberian zat pengatur tumbuh mengandung plant growth regulator dapat mempercepat pertumbuhan tanaman dengan jumlah pemberian sangat rendah (Anwar, Aryani dan Saputra, 2015).

Perlakuan P2 memberikan hasil yang berbeda nyata dengan perlakuan P1, P3 dan P4 pada semua umur pengamatan. Pertumbuhan panjang tanaman sawi dengan pemberian air kelapa terfermentasi yang mengandung zat mempercepat pertumbuhan auxin dengan kepekatan yang berbeda menghasilkan panjang tanaman sawi yang berbeda nyata. Hal ini menunjukkan perlakuan P2 air kelapa terfermentasi dengan kandungan auxin jumlahnya sesuai untuk memacu pertumbuhan tanaman sawi. Pada perlakuan 
tersebut perendaman benih tanaman sawi dalam air kelapa menghasilkan larutan dengan konsentrasi auxin sesuai kebutuhan guna memacu pertumbuhan tanaman sawi dan berpengaruh pada kecepatan tumbuh yang meningkat pada pertumbuhan sel-sel aktif tumbuh/meristem sehingga menambah panjang tanaman sawi (Yunita, Meirani dan Barus, 2017).

Perlakuan pemberian air kelapa terfermentasi yang mengandung zat pengatur tumbuh auxin pada tanaman sawi mempengaruhi jumlah daun tanaman sawi. Perkembangan jumlah daun tanaman sawi disajikan pada Tabel 2.

Tabel 2. Analisa rata-rata jumlahn daun sawi (buah) pada perlakuan pemberian air Kelapa terfermentasi

\begin{tabular}{cccccc}
\hline Perlakuan & $20 \mathrm{hst}$ & $30 \mathrm{hst}$ & $40 \mathrm{hst}$ & $50 \mathrm{hst}$ & $60 \mathrm{hst}$ \\
\hline P0 & $2,75 \mathrm{a}$ & $3.75 \mathrm{a}$ & $5.25 \mathrm{a}$ & $6.00 \mathrm{a}$ & $7.00 \mathrm{a}$ \\
P1 & $3.00 \mathrm{ab}$ & $4.75 \mathrm{~b}$ & $6.25 \mathrm{~b}$ & $7.25 \mathrm{~b}$ & $8.50 \mathrm{~b}$ \\
P2 & $4.00 \mathrm{c}$ & $5.75 \mathrm{c}$ & $7.75 \mathrm{c}$ & $9.20 \mathrm{~d}$ & $9.75 \mathrm{c}$ \\
P3 & $3.25 \mathrm{~b}$ & $5.00 \mathrm{~b}$ & $6.25 \mathrm{~b}$ & $7.25 \mathrm{~b}$ & $8.50 \mathrm{~b}$ \\
P4 & $3.00 \mathrm{ab}$ & $4.75 \mathrm{~b}$ & $6.50 \mathrm{~b}$ & $7.75 \mathrm{c}$ & $8.50 \mathrm{~b}$ \\
\hline
\end{tabular}

Keterangan: Angka pada satu kolom dengan diikuti huruf sama menunjukkan tidak berbeda nyata (uji BNJ, $\alpha \leq 0.05$ dengan aplikasi program SPSS) hst : hari setelah tanam

\begin{abstract}
Jumlah daun tanaman sawi yang terbentuk pada semua perlakuan pemberian air kelapa terfermentasi menunjukkan perbedaan yang nyata dengan perlakuan P0. Pada P0 di mana tanaman sawi tidak diberi air kelapa terfermentasi yang mengandung zat pengatur tumbuh auxin menghasikan jumlah daun tanaman sawi paling rendah. Sedangkan pada tanaman yang diberi limbah air kelapa yang difermentasi yang terdapat auxin
\end{abstract}

mampu meningkatkan jumlah daun tanaman sawi. Perendaman benih tanaman sawi pada limbah air kelapa terfermentasi yang mengandung zat pengatur tumbuh auxin mampu memacu pertumbuhan sel-sel tanaman yang aktif tumbuh/meristematis tanaman khususnya pada meristem bagian ujung/apikal saat pembibitan untuk pembentukan daun sampai pertumbuhan tanaman, sehingga meningkatkan jumlah daun tanaman 
sawi. Pemberian zat pengatur tumbuh yang sangat rendah tidak berperan mempercepat pertumbuhan tanaman (Jumadi, Liawati dan Hartono, 2015).

Perlakuan P2 pada perendaman benih tanaman sawi yang direndam zat pengatur tumbuh auxin berupa air kelapa terfermentasi memberikan pengaruh yang tertinggi pada pembentukan jumlah daun tanaman sawi. Pengaruh yang berbeda ditunjukkan oleh jumlah pemberian air kelapa terfermentasi yang mengandung zat pengatur tumbuh auxin yang berbeda. Pemberian air kelapa terfermentasi yang mengandung zat pengatur tumbuh auxin pada jumlah yang kecil belum mampu memacu pembentukan daun tanaman sedangkan pemberian limbah air kelapa terfermentasi yang mengandung hormon auxin pada jumlah yang banyak mengakibatkan terhambatnya pembentukan daun. Aplikasi zat pengatur tumbuh pengaruhnya berdasarkan pada kepekatan zat yang optimum, dimana mempunyai batas kisaran konsentrasi yang berhimpitan yaitu batas kepekatan antara pengaruhnya mempercepat pertumbuhan dengan kepekatan menghambat/sebagai racun pada pertumbuhan tanaman (Anwar, Aryani dan Saputra, 2015).

Pemberian air kelapa terfermentasi yang mengandung zat pengatur tumbuh auxin pada benih tanaman sawi mempengaruhi berat basah dan berat kering tanaman sawi.

Tabel 3. Analisa rata-rata berat basah dan berat kering (g) pada perlakuan pemberian air kelapa terfermentasi $(60 \mathrm{hst})$

\begin{tabular}{ccc}
\hline Perlakuan & Berat basah tanaman & Berat kering tanaman \\
\hline P0 & $55.59 \mathrm{a}$ & $4.50 \mathrm{a}$ \\
P1 & $90.78 \mathrm{~b}$ & $5.75 \mathrm{~b}$ \\
P2 & $119.14 \mathrm{c}$ & $8.85 \mathrm{c}$ \\
P3 & $88.64 \mathrm{~b}$ & $5.90 \mathrm{~b}$ \\
P4 & $88.57 \mathrm{~b}$ & $6.00 \mathrm{~b}$ \\
\hline
\end{tabular}

Keterangan : Angka pada satu kolom dengan diikuti huruf sama menujukkan tidak berbeda nyata (uji BNJ, $\alpha \leq 0.05$ dengan aplikasi program SPSS) hst : hari setelah tanam

Berat basah pada perlakuan P0 menunjukkan hasil berbeda nyata dengan P1, P2, P3 dan P4. Pada perlakuan tersebut kandungan zat pengatur tumbuh auxin berupa air kelapa terfermentasi yang diberikan 
pada masing-masing perlakuan mempercepat pertumbuhan sel-sel muda pada tanaman yang aktif tumbuh (meristem) pada tanaman sawi untuk membentuk jaringan sel dalam menghasilkan timbunan makanan dari hasil proses metabolisme/biomassa tanaman dan simpanan serapan air dalam tubuh tanaman sawi menghasilkan berat segar tanaman yang lebih banyak. Berat segar/biomassa tanaman merupakan hasil timbunan yang optimal pada aktivitas metabolisme sel-sel dalam jaringan tanaman dalam menghasilkan cadangan makanan dan serapan air dalam proses metabolisme tanaman (Yunita, Meirani dan Barus, 2017).

Pemberian air kelapa terfermentasi yang terdapat kandungan zat pemacu pertumbuhan auxin menghasilkan berat kering tanaman sawi yang berbeda. Perlakuan P0 menunjukkan berbeda nyata dengan perlakuan lainnya. Peningkatan berat kering tanaman sawi disebabkan oleh bertambahnya akumulasi biomassa yang disimpan dari hasil proses metabolisme selama masa pertumbuhan tanaman sawi dengan penambahan jumlah organ penyusun tanaman meliputi panjang tanaman, jumlah daun, akar tanaman serta penimbunan cadangan makanan. Pertumbuhan dan penyimpanan cadangan makanan dalam tanaman memanfaatkan biomassa tanaman berupa berat kering tanaman (Yunita, Meiriani, Barus. (2017).

\section{KESIMPULAN}

Perlakuan aplikasi air kelapa terfermentasi yang mengandung zat pengatur tumbuh auxin mempengaruhi panjang tanaman dan jumlah daun tanaman sawi pada umur 20 sampai 60 hst. Aplikasi zat pengatur tumbuh auxin dari isolasi air kelapa terfermentasi limbah air kelapa terfermentasi yang mengandung zat pengatur tumbuh auxin pada perlakuan P2 menghasilkan berat basah dan bering tanaman sawi yang tertinggi saat panen.

\section{DAFTAR PUSTAKA}

$\begin{array}{lr}\text { Agampodi, V.A. dan B. } & \text { B. } \\ \text { Jayawerdana. } & \text { and } \\ \text { Identificaton } & \text { Characterizatio of at Growth } \\ \text { Regulators Present in Coconut } \\ \text { (Cocos nucifera) Water Using } \\ \text { HPLC (High Performance } \\ \text { Liquid Chromatography). } \\ \text { Proceedings of thse Annual }\end{array}$


Research Symposium. Faculty of Graduate Studies. University of Kelaniya.

Dewi, T.K., J. Suryanggono, D. Agustiyani. 2016. Isolasi dan Uji Aktifitas Bakteri Penghasil Hormon Tumbuh IAA (Indole3-Acetic Acid) dan bakteri Perombak Protein dari Tanah Pertanian Tual, Maluku Tenggara. Proseding SemNas Masyarakat Biodiv Indonesia. 2 (2): 271-276.

Anwar, R., F. Aryani dan S. Saputra. 2015. Pengaruh Penambahan Fermentasi Air Kelapa Terhadap Efektifitas Glifosat Dalam Membunuh Alang-alang (Imperata cylindra L.). Jurnal Agroqua. 13 (1): 17-21.

Djamhuri, E. 2011. Pemanfaatan Air Kelapa untuk Meningkatkan Pertumbuhan Stek Pucuk Meranti (Shorea leprosula Miq.). Jurnal Silvikultur Tropika 02 (01): 58.

Jumadi, S., Liawati dan Hartono. 2015. Produksi Zat Pengatur
Tumbuh IAA (Indole Acetic Acid) dan Kemampuan Pelarutan Posfat pada Isolasi Bakteri Penambat nitrogen Asal Kabupaten Takalar. Jurnal Biologi. 16(1): 43-48.

Yunita, M., Meiriani, A. Barus. 2017. Pertumbuhan Berbagai Umur Bahan Tanam Bud Set Tebu (Saccharum officinarum L.) dengan Konsentrasi NAA yang Berbeda, Jurnal Agroekoteknologi FP USU. 5(2): 297-306.

Yunus, Y., M., Rahayu, Samanhudi, B. Pujiasmanto, H.J. Riswanda. 2016. Respon Kunir Putih (Kaempferia rotunda) terhadap Pemberian IBA dan BAP pada Kultur In Vitro. Agrosains. 18(2): 44-49.

Yong, J.W.H., Liya Ge, Yan Fei Ng dan Swee Ngin Tan. 2009. The Chemical Composition and Biological properties of Coconut (Cocos nucifera L.) Water. Journal Molecules. 5144-5164. 